\title{
Evaluating viral marketing: isolating the key criteria in insurance industry
}

\author{
Maria Gooyandeh Hagh*
}

Department of Management, Payame Noor University, Tehran, Iran

\begin{tabular}{|c|c|}
\hline C H R O N I C L E & A B S T R A C T \\
\hline $\begin{array}{l}\text { Article history: } \\
\text { Received January 20, } 2015 \\
\text { Received in revised format } 28 \\
\text { February } 2015 \\
\text { Accepted } 22 \text { April } 2015 \\
\text { Available online } \\
\text { April } 272015 \\
\text { Keywords: } \\
\text { Insurance firm } \\
\text { Virtual marketing }\end{array}$ & $\begin{array}{l}\text { This paper presents an empirical investigation to determine the key criteria that viral marketing } \\
\text { practitioners believe should be implemented to measure about the success of viral marketing } \\
\text { campaigns in insurance industry. The study designs a questionnaire in Likert scale where the } \\
\text { effects of four independent variables, personal, message, media and tools characteristics are } \\
\text { measured on an Iranian insurance firm's reputation as well as service expansion. Cronbach } \\
\text { alphas were measured for all components of the survey and they were all well above the } \\
\text { minimum acceptable level. Using regression analysis, the study has determined positive and } \\
\text { meaningful relationships between insurance firm's reputation as well as service expansion and } \\
\text { four independent variables. }\end{array}$ \\
\hline
\end{tabular}

\section{Introduction}

During the past few years, there has been growing trend on Internet expansion and many people use various service through Internet facilities (Cakim, 2007). An efficient website with rich content may provide an inexpensive way to advertise through cyberspace (Moon \& Kwon, 2011). While placing a single few-second-long advertisement may cost significant amount of money for firms on television, planning an advertisement on many well reputed websites do not cost significantly (Sekolovska, 2012). Reduce costs, mitigate risks, access to services in all places and all times, enabling the service to a large number of simultaneous users, allowing the creation of databases based on customer preferences are among several advantages of using Internet to introduce services (Koc, 2006). These issues may provide grounds for recognition of the interests and preferences of users and potential customers to provide Web-based behavior analysis. Reducing the level of financial risks in developing new businesses is also one of the most important capabilities of the Internet to create new businesses are increasing.

\footnotetext{
* Corresponding author. Tel: +989122942412

E-mail address: maria.gooyandehhagh@gmail.com (M. Gooyandeh Hagh) 
During the past few years, there have been many studies on measuring the effects of various Internet based advertisements on firm's reputation. Adamides and Voutsina (2006), for instance presented a survey of the co-evolution of manufacturing and marketing strategies as resource and capability building processes based on the competence perspective of strategic management. There are many studies on measuring the effects of market diversification strategies on risk reduction (Aspelund et al., 2007) Brunori \& Cerruti (2008), for instance, analysed two marketing networks developed by farmers in marginal rural areas to add and retain value to produce. Chan et al. (2004) developed a dynamic model of co-specialized resources for competitive advantage.

Constantinides and Fountain (2008) identified the technological and commercial characteristics of the new category of online applications commonly explained as Web 2.0 or Social Media. The study investigated the relevance of Web 2.0 for Marketing Strategy and for Direct Marketing. They explain that while many stated Web 2.0 as a new stage in the evolution of the internet, others simply denied it as a new High-Tech hype while there is still no clear definition and demarcation of the term. Even without a precise definition and in spite of lack of extensive research, the corporate world appear to embrace the Web 2.0 concept.

\section{The proposed study}

This study designs a questionnaire in Likert scale to measure the effects of four independent variables, personal, message, media and tools characteristics on an Iranian insurance firm's reputation as well as service expansion. Fig. 1 demonstrates the structure of the proposed study.

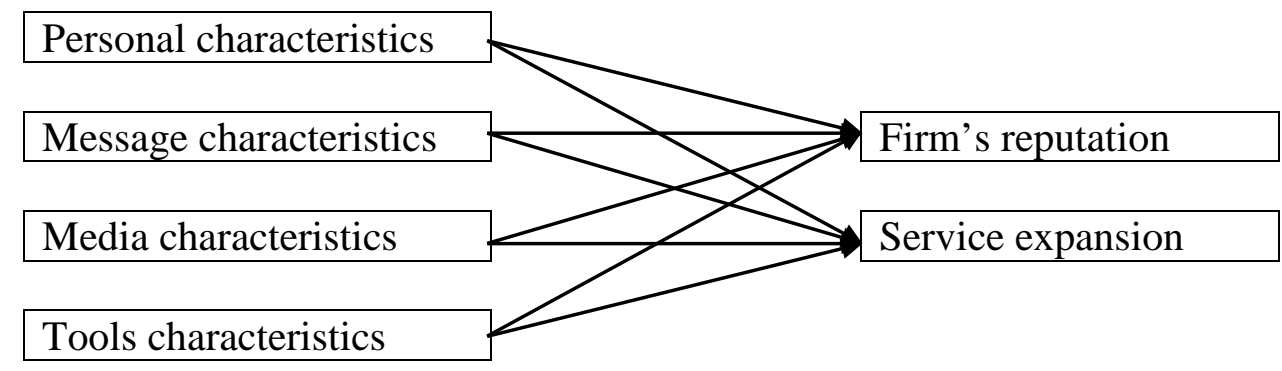

Fig. 1. The proposed study

The questionnaire has been distributed among some experts and they validated the overall questionnaire. In addition, the study selected three insurance consumer and asked them to carefully fill in the questionnaire. Cronbach alphas for Personal characteristics, Message characteristics, Media characteristics and Tools characteristics were $0.73,0.693,0.626$ and 0.737 , respectively. In addition Cronbach alphas for Firm's reputation and Service expansion were 0.755 and 0.793, respectively. Finally, Cronbach alpha for total items of the questionnaire was calculated as 0.906, which confirms the overall questionnaire. The survey determines the sample size of the questionnaire as follows,

$$
N=Z_{\alpha / 2}^{2} \frac{p \times q}{e^{2}},
$$

where $N$ is the sample size, $p=1-q$ represents the probability, $z_{\alpha / 2}$ is CDF of normal distribution and finally $\varepsilon$ is the error term. For our study we assume $p=0.5, z_{\alpha / 2}=1.96$ and $e=0.05$, the number of sample size is calculated as $N=96$. Fig. 2 demonstrates personal characteristics of the participants. 


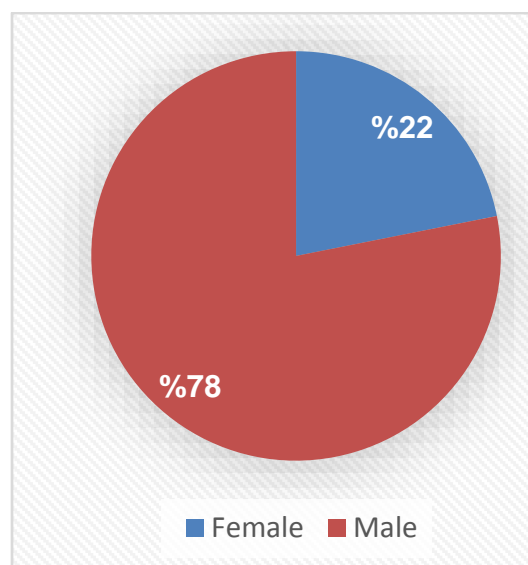

Gender

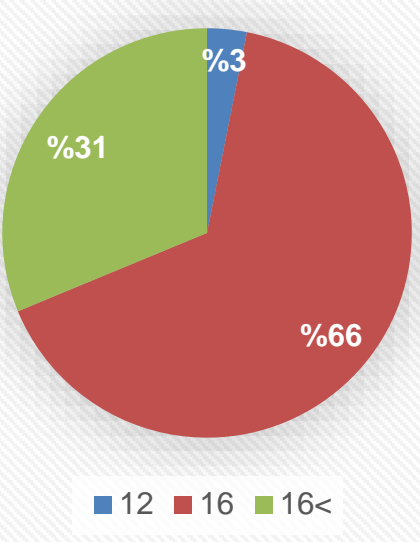

Years of education

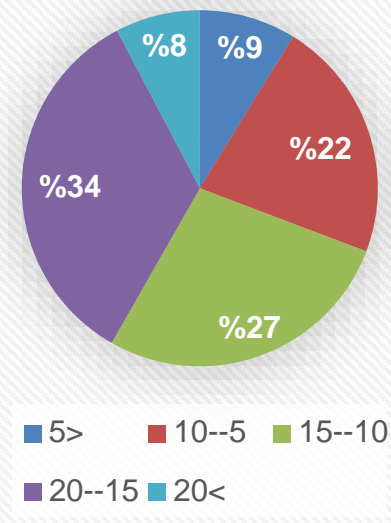

Work experience

Fig. 2. Personal characteristics of the participants

According to Fig. 2, most participants in our survey were highly educated male with good job experiences. Table 1 presents some basic statistics about the components of the survey.

\section{Table 1}

The summary of some basic statistics

\begin{tabular}{lccccc}
\hline Variable & $\mathrm{N}$ & Min & Max & Mean & Standard deviation \\
\hline Customers' cultural characteristics & 96 & 3 & 5 & 4.2812 & 0.55002 \\
Customers' social characteristics & 96 & 2 & 5 & 3.7188 & 0.6794 \\
Customers' personal characteristics & 96 & 1.75 & 4.75 & 3.1953 & 0.55394 \\
Customers' physiological characteristics & 96 & 2 & 5 & 3.6198 & 0.70148 \\
Message content & 96 & 1.78 & 4.89 & 3.6597 & 0.57517 \\
Media characteristics & 96 & 2.38 & 4.75 & 3.5182 & 0.52471 \\
Tools characteristics & 96 & 2.2 & 5 & 3.9208 & 0.64005 \\
Reputation & 96 & 1.33 & 4.83 & 3.5764 & 0.58185 \\
Market expansion & 96 & 1 & 5 & 3.9479 & 0.73799 \\
Financial performance & 96 & 1.5 & 5 & 3.5651 & 0.56457 \\
\hline
\end{tabular}

Kolmogorov-Smirnov test has indicated that all components of the survey were normally distributed. Therefore, we may use parametric tests to verify the hypotheses of the survey. Table 2 demonstrates the results of Pearson correlation.

\section{Table 2}

The summary of Pearson correlation

\begin{tabular}{lcccccc}
\hline Variable & & $\begin{array}{c}\text { Customer } \\
\text { characteristics }\end{array}$ & $\begin{array}{c}\text { Message } \\
\text { content }\end{array}$ & Media & Tools & Reputation \\
\hline Message & $\mathrm{R}($ Sig. $)$ & $.647^{* *}(0.000)$ & & & & \\
Media & $\mathrm{R}($ Sig. $)$ & $.667^{* *}(0.000)$ & $.552^{* *}(0.000)$ & & & \\
Tools & $\mathrm{R}($ Sig. $)$ & $.629^{* *}(0.000)$ & $.604^{* *}(0.000)$ & $.699^{* *}(0.000)$ & & \\
Reputation & $\mathrm{R}($ Sig. $)$ & $.387^{* *}(0.000)$ & $.434^{* *}(0.000)$ & $.537^{* *}(0.000)$ & $.458^{* *}(0.000)$ & \\
$\begin{array}{l}\text { Service } \\
\text { expansion }\end{array}$ & $\mathrm{R}($ Sig. $)$ & $.408^{* *}(0.000)$ & $.313^{* *}(0.002)$ & $.475^{* *}(0.000)$ & $.527^{* *}(0.000)$ & $.629^{* *}(0.000)$ \\
\hline
\end{tabular}

According to the results of Table 2, there are positive and meaningful relationships among different components of the survey. 


\section{Results}

In this section, we present details of the implementation of the regression technique on examining the effects of four independent variables on firm's reputation as well as firm's service expansion. Table 3 presents the results of our survey.

\subsection{The relationship between firm's reputation/service expansion and customer characteristics}

The first hypothesis of the survey investigates the relationship between firm's reputation/service expansion and customer characteristics. Table 3 presents the results of our survey.

Table 3

The results of regression analysis for testing the effect of customer's personal characteristics on firm's reputation and service expansion

\begin{tabular}{llccccc}
\hline Dependent & Independent & \multicolumn{2}{c}{ Non-standard values } & Standard & t-value & Sig. \\
\cline { 2 - 7 } variable & variable & $\beta$ & Standard error & $\beta$ & & \\
\hline Reputation & Intercept & 2.539 & 0.316 & & 0.044 & 0.000 \\
& Social & 0.279 & 0.084 & 0.326 & 3.339 & 0.001 \\
\hline Service & Intercept & 1.271 & 0.552 & & 2.302 & 0.024 \\
Expansion & Social & 0.380 & 0.134 & 0.283 & 2.835 & 0.006 \\
& Psychological & 0.290 & 0.105 & 0.276 & 2.756 & 0.007 \\
\hline
\end{tabular}

According to the results of Table 3, while consumer's social characteristics influences positively on firm's reputation. In addition, consumer's social and psychological characteristics influence positively on service expansion when the level of significance is one percent.

\subsection{The relationship between firm's reputation/service expansion and message content}

The second hypothesis of the survey investigates the relationship between firm's reputation/service expansion and message content. Table 4 presents the results of our survey.

Table 4

The results of regression analysis for testing the effect of message content on firm's reputation

\begin{tabular}{|c|c|c|c|c|c|c|}
\hline \multirow{2}{*}{$\begin{array}{l}\text { Dependent } \\
\text { variable }\end{array}$} & \multirow{2}{*}{$\begin{array}{l}\text { Independent } \\
\text { variable }\end{array}$} & \multicolumn{2}{|c|}{ Non-standard values } & \multirow{2}{*}{$\frac{\text { Standard }}{\beta}$} & \multirow[t]{2}{*}{ t-value } & \multirow[t]{2}{*}{ Sig. } \\
\hline & & $\beta$ & Standard error & & & \\
\hline \multirow[t]{2}{*}{ Reputation } & Intercept & 1.970 & 0.348 & & 5.658 & 0.000 \\
\hline & Message & 0.439 & 0.094 & 0.434 & 4.668 & 0.000 \\
\hline Service & Intercept & 2.477 & 0.466 & & 5.321 & 0.000 \\
\hline Expansion & Message & 0.402 & 0.126 & 0.313 & 3.198 & 0.002 \\
\hline
\end{tabular}

According to the results of Table 4, message content influences positively on firm's reputation and service expansion when the level of significance is one percent.

\subsection{The relationship between firm's reputation/service expansion and media}

The third hypothesis of the survey investigates the relationship between firm's reputation/service expansion and message content. Table 5 shows the results of our survey.

\section{Table 5}

The results of regression analysis for testing the effect of media content on firm's reputation

\begin{tabular}{llccccc}
\hline Dependent & Independent & \multicolumn{2}{c}{ Non-standard values } & Standard & t-value & Sig. \\
\cline { 3 - 7 } variable & variable & $\beta$ & Standard error & $\beta$ & & \\
\hline Reputation & Intercept & 1.481 & 0.343 & & 4.317 & 0.000 \\
& Media & 0.595 & 0.096 & 0.537 & 6.172 & 0.000 \\
\hline Service & Intercept & 1.599 & 0.454 & & 3.520 & 0.001 \\
Expansion & Media & 0.668 & 0.128 & 0.475 & 5.230 & 0.000 \\
\hline
\end{tabular}


According to the results of Table 5, media content influences positively on firm's reputation and service expansion when the level of significance is one percent.

\subsection{The relationship between firm's reputation/service expansion and tools}

The fourth hypothesis of the survey investigates the relationship between firm's reputation/service expansion and message content. Table 6 presents the results of our investigation.

\section{Table 6}

The results of regression analysis for testing the effect of tool content on firm's reputation

\begin{tabular}{llccccc}
\hline \multirow{2}{*}{$\begin{array}{l}\text { Dependent } \\
\text { variable }\end{array}$} & Independent & \multicolumn{2}{c}{ Non-standard values } & Standard & t-value & Sig. \\
\cline { 2 - 7 } variable & $\beta$ & Standard error & $\beta$ & & \\
\hline Reputation & Intercept & 1.943 & 0.331 & & 5.869 & 0.000 \\
& Tool & 0.417 & 0.083 & 0.458 & 4.999 & 0.000 \\
\hline Service & Intercept & 1.565 & 0.401 & & 3.898 & 0.000 \\
Expansion & Tool & 0.608 & 0.101 & 0.527 & 6.014 & 0.000 \\
\hline
\end{tabular}

Based on the results of Table 5, we can conclude that tool content could influence positively on firm's reputation and service expansion when the level of significance is one percent.

\section{Conclusion}

In this paper, we have presented an empirical investigation to study the effects of different variables on market expansion as well as insurance firm's reputation. The study has implemented a questionnaire based survey among 96 randomly selected regular consumers of an insurance firm in Iran. Using Pearson correlation as well as stepwise regression technique, the study has determined positive and meaningful relationship between social characteristics of the participants and firm's reputation. In addition, psychological factor along with social characteristics also influence on firm's market expansion. The study also has determined a positive and meaningful relationships between message, media and tool's characteristics on one side and firm's reputation as well as firm's expansion on the other side. The results of this survey are consistent with findings of Cruz and Fill (2008).

\section{Acknowledgement}

The author would like to thank the anonymous referees for constructive comments on earlier version of this paper.

\section{References}

Adamides, E. D., \& Voutsina, M. (2006). The double-helix model of manufacturing and marketing strategies. International Journal of Production Economics, 104(1), 3-18.

Aspelund, A., Koed Madsen, T., \& Moen, Ø. (2007). A review of the foundation, international marketing strategies, and performance of international new ventures. European Journal of Marketing, 41(11/12), 1423-1448.

Brunori, G., \& Cerruti, R. (2008). Differentiation strategies and marketing networks: Evidence from breeders in two marginal areas of Tuscany. InMediterranean livestock production: uncertainties and opportunities. Proceedings of the 2nd Seminar of the Scientific-Professional Network on Mediterranean Livestock Farming (RME), Zaragoza, Spain, 18-20 May 2006.(pp. 347-359). Centre International de Hautes Etudes Agronomiques Méditerranéennes.

Cakim, I. (2007). Online opinion Leaders: A predictive guide for viral marketing campaigns. Connected Marketing, 107. 
Chan, L. L., Shaffer, M. A., \& Snape, E. (2004). In search of sustained competitive advantage: the impact of organizational culture, competitive strategy and human resource management practices on firm performance. The International Journal of Human Resource Management, 15(1), 17-35.

Constantinides, E., \& Fountain, S. J. (2008). Web 2.0: Conceptual foundations and marketing issues. Journal of Direct, Data and Digital Marketing Practice,9(3), 231-244.

Cruz, D., \& Fill, C. (2008). Evaluating viral marketing: isolating the key criteria. Marketing Intelligence \& Planning, 26(7), 743-758.

Koc, E. (2006). "Order three advertisements and get one news story free”: Public relations ethics practices of Turkish and international companies in Turkey. Public Relations Review, 32(4), 331340.

Moon, Y., \& Kwon, C. (2011). Online advertisement service pricing and an option contract. Electronic Commerce Research and Applications, 10(1), 38-48.

Sekolovska, M. (2012). Internet business models for e-Insurance and conditions in republic of Macedonia. Procedia-Social and Behavioral Sciences, 44, 163-168. 